Dr. Balajti István*

\title{
A hiperszonikus fegyverek hatása a légvédelemre és a légtérellenőrzésre
}

$\mathrm{P}$ eter W. Mattes hírszerző - az Amerikai Egyesült Államok Légierejének (USAF) őrnagya - szerint a korszerủ integrált légvédelmi rendszerek (Integrated Air Defense Systems - IADS) közel húszévnyi alacsony fenyegetettségben való üzemeltetési környezet után, újra a védelmi tervezés élvonalába kerültek. [1] Ezt a megállapítást támasztja alá, hogy a közelmúltban műszaki paramétereit tekintve középkategóriás légvédelmi rendszerekkel sikerült megsemmisíteni nagy magasságban tevékenykedő, nagyon drága, rádióelektronikai felderítésre fejlesztett drónokat. $\mathrm{Az}$ újabb fejlesztésű orosz és kínai IADS hatékonyága, az egymást többszörösen átfedő párhuzamos „rendszer a rendszerben” koncepció alkalmazásával rendkívüli mértékben megnőtt. Továbbá az orosz és kínai IADS aktív zavarvédelme csak rendkívül nagy erőfeszítések árán sebezhető. A napjainkban széleskörủen elterjedt légvédelmi rendszerek ismert hiányosságaira hívja fel a figyelmet az Amerikai Egyesült Államok Kongresszusának a hiperszonikus fegyverekről (továbbiakban: HyW - Hypersonic Weapon) írt jelentése. [2] A tanulmány célja a HyW légtérellenőrzésre gyakorolt hatásának bemutatása, és az ahhoz kapcsolódó feladatok, valamint az idő- és költségvonzatának felvázolása. Ezek ismerete a magyar szakemberek, döntéselőkészítők és döntéshozók számára is fontos, hiszen a légterünkben zajló események detektálása, dokumentálása és a légtérellenőrzés biztonsága alapvető elvárás egy szuverén országgal szemben. További fontos tény, hogy a világür gazdasági lehetőségeinek kiaknázása megköveteli a hazai légtér és az a feletti földközeli műholdpályák figyelését, amelyet Magyarország saját erőforrások bevonásával oldhat meg. Ahogy Kositzky Attila altábornagy, a Magyar Légierő parancsnoka az 1990 évek közepén fogalmazott: „Mint Légierő Parancsnoknak tudnom kell, hogy ki és honnan osztja a pofonokat, még ha nem is tudok ellene védekezni".

\section{A HIPERSZONIKUS FEGYVEREK LEGFONTOSABB JELLEMZŐI}

A kongresszusi jelentés röviden összefoglalja az USA, Oroszország és Kína HyW-fejlesztések területén elért eredményeit. A jelentés megállapításai és javaslatai nyílt szakirodalomban fellelhető tényeken alapulnak, amelyek szerint a hiperszonikus fegyvereknek két fő típusa különböztethető meg:

- Hiperszonikus „sikló/cikázó” repülőeszközök - (Hypersonic Glide Vehicles [HGV]), amelyeket rakétákkal indítanak, és rakétamotorral, „sikló/cikázó” útvonalon érik el a célterületet.

- Hiperszonikus cirkáló „rakéta”/eszközök - (Hypersonic Cruise Missiles [HCM]), amelyek „hiper” sugárhajtású hajtómüvel rendelkeznek².

A HyW alkalmazásában rejlő előnyök:

- Rendkívül nagy, a hangsebességet legalább ötszörösen - de akár hússzorosan is - meghaladó sebesség. Ennek következtében a légvédelem reakcióideje ötöd, illetve húszad részére csökken. Az 1. ábra szemlélteti az Airbus A320, a Saab JAS-39 Gripen, az Lockheed SR-71/MiG-25 és egy HyW által 20 perc alatt megtehető távolságok összehasonlítását.

- A felső légkörben 23-60 km magasságtartományban manőverezve haladnak, mint az eldobott, víz felszínén „kacsázó” lapos kövek. Megfelelő vezérléssel nagy
ÖSSZEFOGLALÁS: Napjainkban a hiperszonikus fegyverek megjelenése minden nemzet haderejében kiemelt figyelemben részesül, mivel az ellenük történő védelem kiterjesztett célkutatást, útvonalképzést, céltárgyazonosítást és megsemmisítést követel meg. Ennek oka, hogy a hiperszonikus fegyverrendszerek nagyon nagy sebességgel, gyorsulással és magassági tartományban $(23-60 \mathrm{~km})$ üzemelnek. Ugyanakkor kis radarkeresztmetszettel (RCS) jellemezhetők, amely manőverezés közben jelpolarizáció-ingadozást okoz a VHF-rezonáns frekvenciasávban. Az újonnan megjelent fegyverek képességeihez való alkalmazkodás és a kapcsolódó katonai múveletek tervezése megkövetelik, hogy részletes és naprakész tanulmányok készüljenek az elöregedő, és a korszerú radarhálózatok műszaki lehetőségeinek kiterjesztéséről. A jelenleg működő radarhálózatok infrastruktúrája, meglévő üzemeltetési és környezetvédelmi engedélyei ${ }^{1}$ nagyon hasznosak az újonnan megjelenő fenyegetésekkel szembeni fejlesztések szempontjából. A javasolt megközelítés ötvözi és optimalizálja a passzív radar, a modernizált hagyományos radarhálózatok és a napjainkban kifejlesztett rádiólokátorok információfeldolgozását, miközben kiterjeszti a radarmérések szabadságfokát.

KULCSSZAVAK: hiperszonikus fegyverek, rakétavédelmi rendszerek, rádiólokátor-rendszer fejlesztés, rádióelektronikai harc
ABSTRACT: Hypersonic Weapons have emerged and have received very high attention because the defense against them requires ubiquitous surveillance, tracking, recognition and destruction. The reason is that the Hypersonic Weapon systems operate at very high speeds, accelerations and altitudes, between $23 \mathrm{~km}$ and $60 \mathrm{~km}$. It characterizes by low Radar Cross Section (RCS), which has resonant Region in VHF frequency band with signal polarization fluctuation as it maneuvers. The implementation of extending technical resources of aging and indeed modern radar networks requires detailed consideration to be up to date and adopted into newly emerged weapons capabilities and their military operations. The infrastructure and existing operational authorizations and environmental permissions of the currently in operation radar networks are very vulnerable for upgrades against emerging threats. The proposed approach is an optimization of information extraction of Combined Passive Radar, Modernized Traditional Radar Networks and Newly Developed Radars with extension of the radar Measurement Degree of Freedom.

KEY WORDS: Hypersonic Weapons, antimissile systems, radar system development, Electronic Warfare

\footnotetext{
National University of Public Service. Doctoral School of Military Engineering. ORCID: 0000-0003-3566-2904
} 


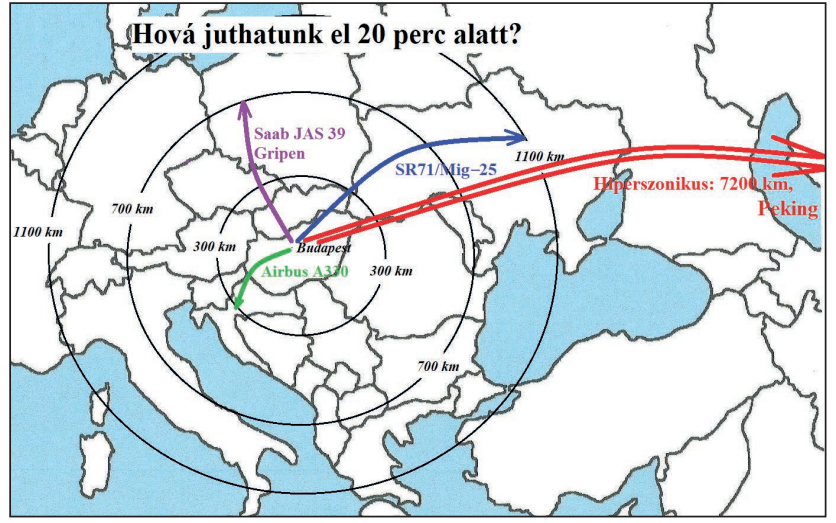

1. ábra. Budapest légteréből különböző repülőeszközökkel 20 perc alatt megtehető távolságok

manőverező képesség érhető el. Ennek köszönhetően az 1. ábrán látható Budapest-Peking útirány egyszerüen Budapest-Indiai-óceán célterületre változtatható, szemben az interkontinentális rakéták könnyen kiszámítható, kötött röppályájával.

- A hiperszonikus fegyverek detektálása és útvonalba fogása nem hagyományos radarrendszerrel történik, mivel azok célfelderítési terei fölött repülnek. A detektálás az interkontinentális rakéták ellen kifejlesztett rendszerekkel sem lehetséges, mivel ez utóbbi esetben a HyW alatta marad az elvárt repülési magasságoknak és röppályáknak. Mindkét esetben a rádiólokátorok által detektált céljelekből plotot (a céltárgyra és helyzetére vonatkozó kiértékelt szintetikus információt) képeznek, majd ezekből a plotokból a harcvezetési központ „többradaros útvonalképzője” útvonalat képez és tart fenn. Az útvonalak képzése azért fontos, mivel az a rádiólokátor-adatfeldolgozás első olyan eleme, amelyre feladatot lehet szabni. Például azonosítani lehet a repülő tárgyat. Ha a céltárgyat a rádiólokátor nem képes detektálni, elmarad a plotképzés. Plotok nélkül nincs útvonal, és útvonalak nélkül fel sem merülhet azok azonosítása. Ha a céltárgy detektálása megtörténik, de az útvonalképző (helyben vagy a központban) „hamis” plotként kiszűri azokat, mert nincs

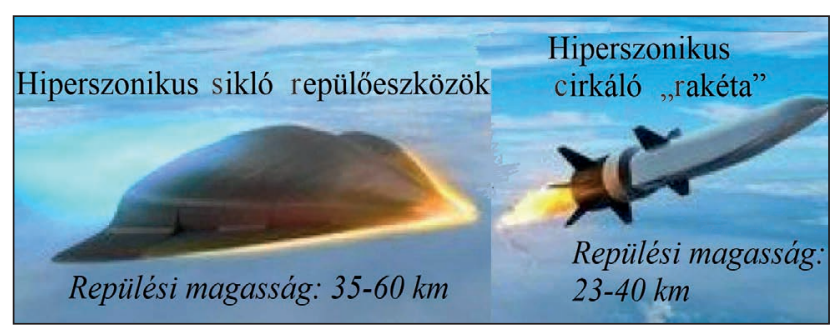

2. ábra. A hiperszonikus repülőeszközök két fő típusának fizikai kialakítása

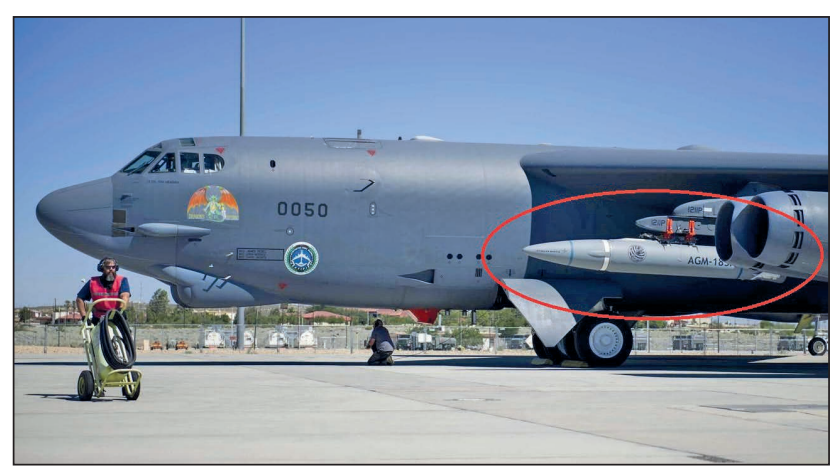

3. ábra. Lockheed Martin AGM-183A HyW, B-52-es indító platformon [3]

felkészítve a HyW paraméterekre, az eredmény az előző gondolatmenethez hasonló lesz. Így mindkét esetben megoldandó új feladat az új típusú céltárgydetektálás, útvonalképzés és céltárgy-azonosítás problematikája.

A HyW két típusának sematikus kialakítása a 2. ábrán látható. A különböző típusok repülési magassága sebességfüggő: minél nagyobb a sebesség, annál magasabban kell repülni a légellenállás csökkentése miatt.

A hiperszonikus fegyverek kutatás-fejlesztése $(K+F)$ területén három ország jár az élen. Ezek közül az USA rendelkezik a legszerteágazóbb programokkal. Több egyetem, kutatóintézet és magáncég foglalkozik a HyW fejlesztésével és a tesztelések részfeladatainak megoldásával.

A legismertebb HyW-programok megrendelőinek nevét, költség- és idővonzatait az 1. táblázat foglalja össze:

1. táblázat. A legismertebb HyW-programok

\begin{tabular}{|c|c|c|c|c|}
\hline Megrendelők & Program neve & $\begin{array}{l}\text { Költségkeret } \\
\text { (mUSD/2020) }\end{array}$ & $\begin{array}{l}\text { Költségkeret } \\
\text { (mUSD/2021) }\end{array}$ & Megjegyzés \\
\hline \multirow{2}{*}{$\begin{array}{l}\text { DARPA } \\
\text { (Defense Advanced Research } \\
\text { Projects Agency - Az USA } \\
\text { Védelmi Minisztériumának } \\
\text { kutatásokért felelős részlege) }\end{array}$} & $\begin{array}{l}\text { Harcászati rakétaindítás } \\
\text { (Tactical Boost Glide - TBG) }\end{array}$ & 152 & 117 & \\
\hline & $\begin{array}{l}\text { Hiperszonikus sugárhajtású } \\
\text { fegyverkoncepció } \\
\text { (Hypersonic Air-breathing Weapon } \\
\text { Concept - HAWC) }\end{array}$ & 20 & 7 & $\begin{array}{l}\text { 2021-ben } \\
\text { várható } \\
\text { rendszeresítés }\end{array}$ \\
\hline $\begin{array}{l}\text { U.S. Navy } \\
\text { (Az USA haditengerészete) }\end{array}$ & $\begin{array}{l}\text { Hagyományos azonnali csapás } \\
\text { (Conventional Prompt Strike - CPS) }\end{array}$ & 512 & 1007 & $\begin{array}{l}\text { Végső tesztek: } \\
2028\end{array}$ \\
\hline $\begin{array}{l}\text { U.S. Army } \\
\text { (Az USA szárazföldi hadereje) }\end{array}$ & $\begin{array}{l}\text { Nagy hatótávolságú HyW } \\
\text { (Long-Range Hypersonic Weapon } \\
\text { - LRHW) }\end{array}$ & 404 & 801 & \\
\hline $\begin{array}{l}\text { U.S. Air Force } \\
\text { (Az USA légiereje) }\end{array}$ & $\begin{array}{l}\text { AGM-183 légi indítású } \\
\text { gyorsreagálású fegyverek } \\
\text { (Air-Launched Rapid Response } \\
\text { Weapon - ARRW) }\end{array}$ & 286 & 382 & $\begin{array}{l}\text { Sikeresen } \\
\text { végrehajtott } \\
\text { tesztek: } 2020 \\
\text { augusztus }\end{array}$ \\
\hline
\end{tabular}




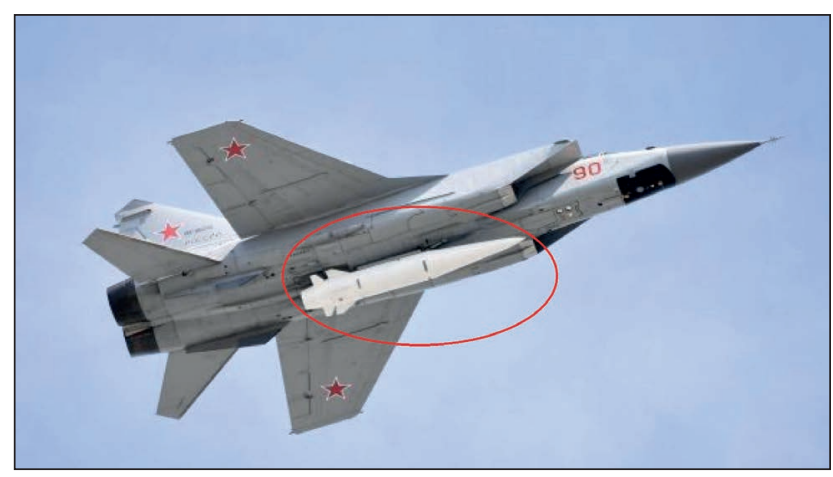

4. ábra. Kh-47M2 Kinzsal hiperszonikus fegyver egy MiG-31K típusú repülőgép külső függesztményeként [3]

Oroszország a HyW-kutatásait - amelyek az utóbbi tíz évben felgyorsultak - az 1980-as években kezdte meg. Az eddig elért legfontosabb eredmények:

- Avangard - a világon az első, 2019. decemberében rendszeresített, $12000 \mathrm{~km}$ hatótávolságú rendszer, amelyben az 5,4 m hosszúságú HyW eszközt interkontinentális rakétával indítják. Rövid ideig a hangsebesség több mint 20-szorosával képes repülni. A nukleáris robbanófej pontosabb célba juttatása érdekében a sebesség a célkörzetben már jelentősen csökken, ezért a repülés utolsó fázisában nyílik a legnagyobb esély a hatékony légvédelemi ellentevékenységre.

- 3M22 Zircon - hadihajókról és tengeralattjárókról indítható, 1000 km-en belül tartózkodó célok ellen alkalmazható. A 8 m hosszúságú repülőeszköz maximális sebessége 8-9 Mach (9800-11000 km/h).

- Kh-47M2 Kinzsal - világelső, 2017 decemberében rendszeresített légi indítású, szilárd üzemanyagú, rakétameghajtással rendelkező rendszer (4. ábra). Hatótávolsága, a hordozó repülőgép függvényében 2-3 ezer km. Maximális sebessége 10-12 Mach (12 250-14 700 km/h). Vezérlése kombinált távirányítású, amelynek összetevői az optikai és inerciális navigáció, kombinálva a GLONASS müholdas helymeghatározási rendszerrel.

Kína hiperszonikus fegyverek területén elért eredményeit a DF-ZF-fel (NATO-kódja WU-14) alapozta meg. A DF-ZF rendszert 5-10-szeres hangsebességre tervezték, 2-3000 km-es hatótávolsággal. Újabb változata interkontinentális rakétával indítható, 12000 km-es hatótávolsággal.

A 11 m hosszú DF-17, Kína legtöbbet emlegetett szárazföldről, hadihajókról és tengeralattjárókról is indítható HyWeszköze (5. ábra). Maximális sebessége 5 Mach (6125 km/h), míg hatótávolsága indítóplatformtól függően: 18002500 km. A Starry Sky-2 (Xing Kong-2) „hullámlovas” kísérleti HyW, amely a hangsebesség 6-szorosával repül.

5. ábra. Repülőgép-hordozók ellen alkalmazható DF-17 típusú HyW [3]

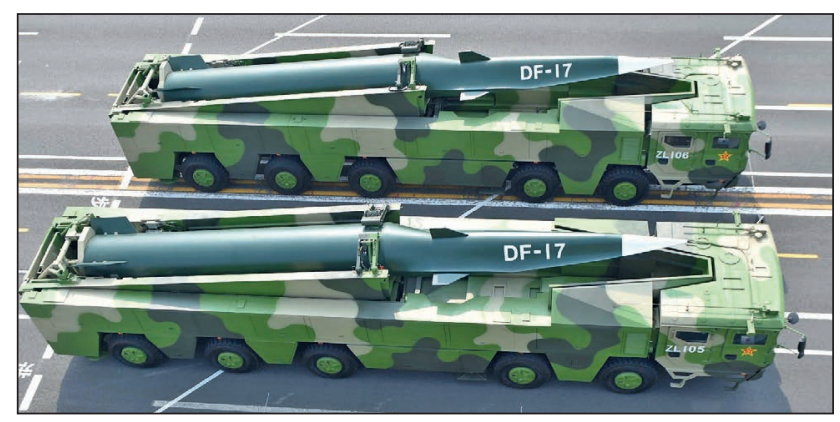

Érdekessége, hogy a maga által összenyomott levegőrétegen manőverező „hiper”-t sugárhajtóművel látták el. Rendszerbe állítása 2025-ben várható.

Mindhárom ország esetén komoly állami, egyetemi és ipari infrastruktúra támogatja a fejlesztéseket. A kongreszszusi tanulmány rámutat a HyW stratégiai megítélésében rejlő ellentmondásokra. Természetesen az említetteken kívül más országok is (pl. India, Irán és Izrael) a hiperszonikus fegyverek fejlesztésének különböző részterületein ugyancsak előrehaladott eredményeket értek el.

\section{A LÉGVÉDELMI RADARRENDSZEREKKEL KAPCSOLATOS ELVÁRÁSOK}

A légtérellenőrzést ellátó radarrendszereket (IADS) gyakran a légvédelem „szemének” nevezik, amely nélkül nem beszélhetünk hatékony légvédelemről. E tanulmány szerzője a HyW előzőleg ismertetett jellemzőit, a légtérellenőrzéssel kapcsolatos elvárásokat, a szakirodalom [4] felhasználásával saját tapasztalatok alapján elemzi, illetve egészíti ki.

Általánosan elfogadott tény, hogy a nagy hatótávolságú légtérellenőrző rádiólokátorok ún. „cosec” négyzetes felderítési terei egy azonos magassági tartományból (kb. 30 km-es magasságig) és egy azonos távolsági tartományból (kb. 450 km-ig) állnak (6. ábra). Ennek következtében a napjainkban széles körben elterjedt radarok nem képesek a hiperszonikus fegyvereket detektálni, útvonalba fogni, az útvonalakat fenntartani és céltárgyként azonosítani. Az azonosítás egy külön eljárásrend, amelyet egyszerübb esetben másodlagos rádiólokátorokkal és barát-idegen felismerő (IFF) rendszerekkel a hadműveleti rendszerek települési helyszínén hajtanak végre. Korszerübb rendszerekben képalkotó radarok segítségével, mesterséges intelligencia alkalmazásával határozzák meg. A radar, és a hadműveleti rendszerek továbbfejlesztése szempontjából fontos HyWjellemzők alábbi szempontok szerinti csoportosítása:

- A HyW-eszközök indíthatók „hagyományos” szárazföldi mobil, vagy fix települési körzetekből, tengeri vagy légi hordozó eszközökről. Ezek valószínűleg már az indítási fázisban a kiépült harcászati-hadászati rakétavédelmi rendszerek érzékelő alrendszereivel megfigyelhetők. Ugyanakkor az észlelések hitelessége rendkívüli mértékben csökkenthető korszerű rádióelektronikai harceszközök és eljárások lokátorok elleni alkalmazásával.

- AHyW-eszközök rendkívül nagy fizikai és hőterhelésnek vannak kitéve, ezért aránylag kis tömeggel rendelkeznek és kompakt felépítésűek (mint azt a 2. 3. 4 és 5. ábrák is illusztrálják). Ennek következtében a hatásos radarcéltárgy-keresztmetszetük (RCS) kicsi, és függ a radar hullámhosszától, polarizációjától, a céltárgy mozgása és a hullámterjedés okozta fluktuációktól, valamint a radarantenna-nyaláb besugárzási irányától. Pesszimista becslés szerint $S$ sávú $(3,1 \mathrm{GHz})$ radarok esetén az RCS = 0,02-0,1 $\mathrm{m}^{2}$ közötti; az $L$ frekvenciasávban $(1,3 \mathrm{GHz})$ ez az érték 0,08-0,3 $\mathrm{m}^{2}$. Emellett a VHF sávban $(0,2 \mathrm{GHz})$ már 0,2-1 m² [5]. A HyW szimulációs modelljei frekvenciatartományonként és megvilágítási szögenként eltérőek. Az Sw1 és Sw3 céltárgytípussokkal modellezhetők, mivel az intenzív plazmaképződés csökkenti a fluktuáció mértékét. A légellenállás okozta nagy hőképződés lehetővé teszi a hatékony hőérzékelő és optikai rendszerek kiépítését.

- A HyW harcászati-hadműveleti rakétákhoz képest alacsony röppályán történő manőverezését a repülés teljes szakaszán irányítani kell. Ennek következtében az irányítási csatornák és megoldások lehetőséget nyújthatnak elektronikai ellentevékenység alkalmazására. 
Következtetésként felsoroljuk a légtérellenőrző nagy hatótávolságú radarrendszerekkel szembeni elvárásokat:

- A hatótávolság megnövelése magasságban legalább 60 km-re, míg távolságban 1200 km-re.

- Sűrűn telepített radarhálózat kiépítése szükséges, illetve a meglévő rendszereket modernizálni kell vagy kiegészíteni a radarok holtkúpjainak lefedésére és a többszörös 3D átfedésű rádiólokációs terek biztosítására.

- A legkorszerübb radaroknak adott irányokban és magassági szektorokban gyorsan mozgatható digitális antennanyaláb-vezérléssel kell rendelkezniük.

- A radarok digitális jelfeldolgozó rendszerét módosítani, illetve kiegészíteni szükséges a jel-zaj (+zavar) viszony növelése érdekében. A feladatra optimalizált jelelőállítást, a valós idejü hullámterjedési és a korrelációs tényezők folyamatos pontosítását kell végrehajtani, amellyel kihasználhatók a koherens jelfeldolgozásban és jelintegrálásban rejlő előnyök.

- Az egyedi radarok adóteljesítményét minimum a duplájára kell növelni, miközben az adójel tisztaságával kapcsolatos követelmények is növekednek.

- Ezek a változások természetesen megkövetelik a központi, hadmúveleti rendszerek jel- és adatfeldolgozó alrendszereinek, valamint a kapcsolódó interfészek módosítását, kiegészítését is.

A hagyományos rádiólokátorok és a hiperszonikus fegyverek detektálására is alkalmas megnövelt rádiólokációs terek egymáshoz való viszonyát szemlélteti a 6. ábra. Megfigyelhető, hogy a HyW csak az új, megnövelt radarperformanciákkal detektálható és fogható útvonalba. Külön problémát jelentenek a radarok holtkúpjai, ahol a hagyományos céltárgyakat már napjainkban sem lehet detektálni. Alacsony magassági tartományokban ez a hiányosság a szomszédos radarokkal kiküszöbölhető. A 6. ábra ebből a szempontból nem elég pontos, mivel a holtkúp alsó szögének nagysága $60-70^{\circ}$-os, ezáltal a magasság növekedésével jelentősen nő a radar által „nem belátható” területek nagysága. Ennek csökkentése és a céltárgydetekció valószínűségének növelése érdekében szükséges az egymást többszörösen átfedő, különböző frekvenciatartományokat egymásba integráló radarrendszerek alkalmazása. Erre példa a 7. ábra, amely bemutatja a napjainkban használt különböző típusú radarrendszerek függőleges céltárgy-detektálási tereit, azok egymáshoz való viszonyát és a különböző indítású HyW repülési profiljait.

A 7. ábrán zöld színnel jelölt - „L” 3D radar (pl. a hazánkban is üzemelő RAT-31DL) - területe túl kicsi ahhoz, hogy a HyW megjelenését detektálja. Ráadásul a terület nagysá-

\section{6. ábra. Hiperszonikus fegyverek detektálására is képes} megnövelt rádiólokációs terek

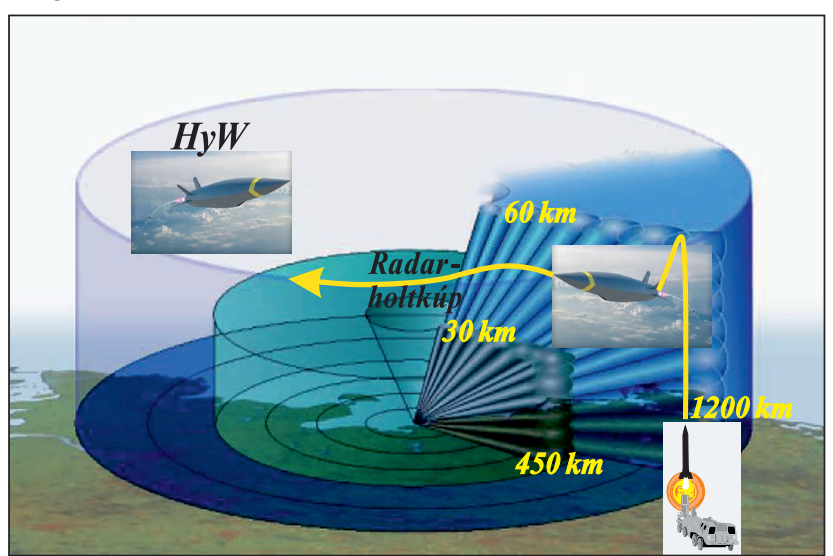

ga, távolságban és magasságban is jelentősen csökkenthető korszerű elektronikai harc (a 7. ábrán ECM jelölés) alkalmazásával. A hagyományos VHF, „m” hullámsávú radarok (pl. a Medinán települt Oborona-14 radar) esetén valamivel jobb a helyzet, mivel már minimális korszerűsítés esetén legalább néhány indítás ténye regisztrálható. A HyWindítások szempontjából jelentős a "horizonton túli radarok" képességeinek kihasználása és az általuk mért adatokhoz történő hozzáférés, mivel ezek a radarok 1-3 ezer km között mérik a harcászati-hadműveleti rakéták indítását. Az előzőekben megállapítottuk, hogy egyre több HyW indítható hagyományos rakétasilókból, mobil platformokról vagy tengeralattjárókról. Bár a röppálya nem ballisztikus, az indítás ténye, valamint a 7 . ábrán jelölt, más esetben kiszámítható „A”, „B” és „C” röppályaelemek hiánya figyelmeztethet a veszély jellegére.

A 7. ábrán bejelölve láthatók azok a perspektivikus rádiólokációs terek, amelyek kialakítása elengedhetetlen a HyW-fegyverek detektálása, útvonalképzése és fenntartása, valamint azonosítása szempontjából. Az ábrán szürkével jelölt „Radarok által nem ellenőrzött térrészek” napjainkban még jelentős nagyságúak - pl. az óceánok partjaitól távoli légterek - amelyek költséghatékony lefedése a polgári légi irányítás szempontjából napjaink és a közeljövő feladatai közzé tartoznak. Az eddig javasolt passzívradaros megoldások erre a problémára nem alkalmazhatók az adórendszerek hiánya, és a műsorszóró adóantennák földközeli térrészekre fókuszált iránya miatt. Megoldást kínálnak a fejlesztés alatt lévő, a 7. ábrán „HyW VHF/UHF” jelöléssel jelzett, nagy teljesítményű radarok, amelyek 1000-1200km távolságig és $60 \mathrm{~km}$ magassági tartományig megoldhatják a HyW megjelenésével bekövetkező kihívásokat. Ugyanakkor a „VHF-radarok”, passzív radaros mérőpontokkal kiegészítve, jelentősen csökkenthetik a napjainkban még nem ellenőrzött térrészek nagyságát. Külön megrendelésre az "L" és „S" sávú radarok rendelkezhetnek harcászati ballisztikus rakéták észlelésére és útvonalba fogására alkalmas kiterjesztett rádiólokációs terekkel, amelyet az „L Kiterj." jelöléssel mutat a 7. ábra. Mint látható, ez a terület korlátozott módon, ideiglenes és aránylag rövid idő alatt megvalósítható fejlesztésekkel, megoldást nyújthat a HyW korlátozott detektálására, és útvonalba fogására.

A 2. táblázat a rádiólokáció egyenletére épülő, ún. Blake Chart számítások alapján, a HyW-fegyverek rendszerbe állásával felmerülő feladatok megoldásához szükséges, a szerző által legfontosabbnak és elvártnak tartott radartípus performanciákat foglalja össze. Az összehasonlítás alapja egy olyan radar, amely azonos céltárgydetekciós minőségi jellemzők $\left(P_{d} / P_{v v}\right)$ és a céltárgy detektálási összveszteségek (20,5 dB) esetén a szabvány céltárgyat 300 km távolságra

7. ábra. Hagyományos radarrendszerek és a HyW detektálási lehetőségeik

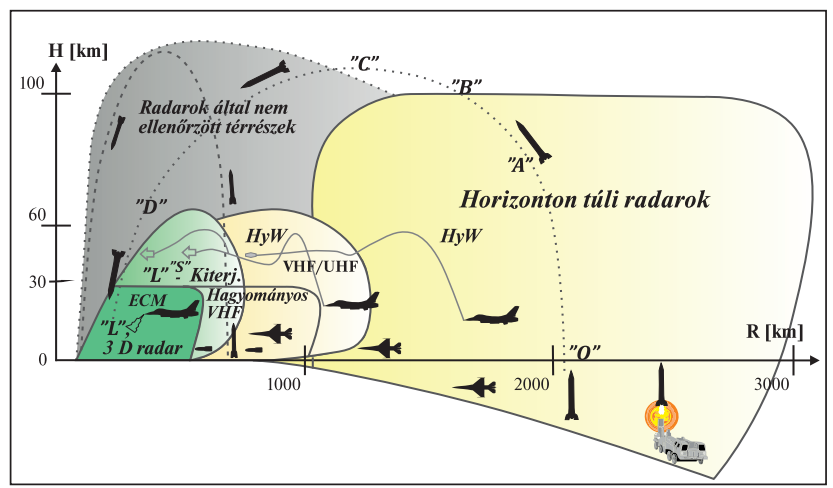


2. táblázat. Különböző típusú repülőeszközök szabvány céltárgyhoz viszonyított detektálási lehetősége

\begin{tabular}{|c|c|c|c|c|c|c|}
\hline \multirow{4}{*}{$\begin{array}{l}\text { RCS }=1 \mathrm{~m}^{2} \\
\text { Sw1/Repülögéptípus }\end{array}$} & \multicolumn{6}{|c|}{$\begin{array}{c}\mathbf{R}_{\max }[\mathbf{k m}]=\mathbf{3 0 0} \mathbf{~ k m}, \\
\text { Szabadtér, } P_{d}=0,8 / P_{v l}=10^{-6}, \text { Nincs frekvencia-diverzitás }=\mathbf{1}(\mathrm{FD})\end{array}$} \\
\hline & \multicolumn{2}{|c|}{$\mathrm{L}(1,3 \mathrm{GHz})$} & \multicolumn{2}{|c|}{$\mathrm{S}(3,1 \mathrm{GHz})$} & \multicolumn{2}{|c|}{ VHF $(0,18 \mathrm{GHz})$} \\
\hline & $F D=1$ & $\mathrm{FD}=2$ & $\mathrm{FD}=1$ & $\mathrm{FD}=2$ & $F D=1$ & $F D=2$ \\
\hline & $300 \mathrm{~km}$ & 349 km & 300 km & $349 \mathrm{~km}$ & $300 \mathrm{~km}$ & 549 km \\
\hline Airbus A320 & $531 \mathrm{~km}$ & 619 km & 447 km & 522 km & $791 \mathrm{~km}$ & $923 \mathrm{~km}$ \\
\hline Saab JAS-39 & $393 \mathrm{~km}$ & 458 km & 332 km & $386 \mathrm{~km}$ & $530 \mathrm{~km}$ & $617 \mathrm{~km}$ \\
\hline SR-71/MiG-25 & $446 \mathrm{~km}$ & 531 km & 394 km & $460 \mathrm{~km}$ & $501 \mathrm{~km}$ & $634 \mathrm{~km}$ \\
\hline HyW & $224 \mathrm{~km}$ & 260 km & 171 km & 199 km & $300 \mathrm{~km}$ & $549 \mathrm{~km}$ \\
\hline
\end{tabular}

Ahol: Airbus A320 RCS $=\left(50 \mathrm{~m}^{2}-\mathrm{VHF}, 10 \mathrm{~m}^{2}-\mathrm{L}, 5 \mathrm{~m}^{2}-\mathrm{S}\right)$, Saab JAS-39 RCS $=\left(10 \mathrm{~m}^{2}-\mathrm{VHF}, 3 \mathrm{~m}^{2}-\mathrm{L}, 1,5 \mathrm{~m}^{2}-\mathrm{S}\right)$,

SR-71/MiG-25 RCS = (8 $\mathrm{m}^{2}-$ VHF, $\left.5 \mathrm{~m}^{2}-\mathrm{L}, 3 \mathrm{~m}^{2}-\mathrm{S}\right), \mathrm{HyW}$ RCS $=\left(1 \mathrm{~m}^{2}-\mathrm{VHF}, 0,3 \mathrm{~m}^{2}-\mathrm{L}, 0,1 \mathrm{~m}^{2}-\mathrm{S}\right)$

képes detektálni. A táblázat megadja a különböző típusú repülőeszközök detekciós távolságát oldalról történő megvilágítás esetére, frekvenciadiverzitás nélküli, egy vivőfrekvencia $(F D=1)$ alkalmazása, és két vivőfrekvencia $(F D=2)$ azonos térrészben történő alkalmazási eseteire. A napjainkban széleskörüen elterjedt $L$, és különösen az $S$ sávú radarok lehetőségeivel szemben, a VHF-radarok HyW detektálási lehetőségei kimagaslóak.

\section{A HyW KIHÍVÁSAINAK MEgFELELŐ RADAROK}

A tanulmány szerzője szerint a legnagyobb feladatot az jelenti, hogy rövid időn belül nagy mennyiségű a HyWfegyverek kihívásainak megfelelő rádiólokátort kell kifejleszteni, telepíteni, a légvédelembe integrálni és folyamatosan fenntartani. A műszaki kihívások megoldásán túl, ki kell fejleszteni az új képességek harcászati alkalmazásának hatékony módszereit is. Az ebben rejlő feladatok komplexitására, a harcászati lehetőségek elvárásainak elemzésére nyújt jó példát a [6] forrás. Nyilvánvaló, hogy a feladat rövid idő alatt nem megoldható. Így számba kell venni a rövid távon megvalósítható elvárásokat, a rendelkezésre álló szakembereket, költség- és idővonzatokat. Eszerint a legperspektivikusabb rendszer-topológia ötvözi a legkorszerübb $3 \mathrm{D}$ radarokat, amelyek digitális antennanyaláb-vezérléssel rendelkeznek, és a már rendszerben lévő radarok fejlesztésében rejlő lehetőségeket. Különösen fontos a már rendszerben lévő radarok modernizálása, hiszen Európában néhány civil szervezet nagyon eredményes az új radarrendszerek telepítésének megakadályozásában, illetve elodázásában. Így Magyarországon felértékelődnek az Oborona-14, RAT-31DL és P-37 radarok és települési helyeik. Hazánk természetesen nem mondhat le a legkorszerűbb, HyW-feladatok detektálására is alkalmas új radarok beszerzéséről sem.

Európában az új radarrendszerek kifejlesztésében, és az eredmények bemutatásában élen jár a német Fraunhofer FHR intézet. (Régebben hasonló célkitűzések tartoztak a Haditechnikai Intézet - HTI néven Magyarországon működő szervezet elektronikai osztályának feladataihoz.) A [7] szakirodalomban az FHR intézet munkatársai összefoglalják a XXI. század korszerünek tekinthető radarrendszereivel szemben támasztott elvárásokat, amelyek a radarrendszer hálózat szintű jelszinkronizálás megoldásai köré csoportosíthatók. Ilyen radarhálózatok a passzív radarok és jelszinkronizálási megoldásaik, amelyek fejlesztésében élen járnak a cseh ERA a.s. és a német Hensoldt A.G. cégek, de magyar kutatók is szép eredményeket értek el ezen a területen. A kutatások középpontjában a kvázi-monostatikus radarok állnak, amelyek koherens jelintegrálással új megoldásokat kínálnak a radarrendszerekkel szemben támasztott követelmények teljesítése érdekében. Ez az elv nem jelent újdonságot a magyar légtérellenőrzés számára, hiszen a szovjet Kabina-66 rendszer ugyancsak ezen az elven működött. Igaz, a kor akkori technikai színvonala csak a nem koherens jelintegrálás módszerének alkalmazását tette lehetővé.

A NATO-tagállamok közül kétségtelenül az USA radarokkal kapcsolatos kutatás-fejlesztési tevékenysége a legfontosabb és a legeredményesebb. A szerteágazó fejlesztések közül - a szerző véleménye szerint - a legfigyelemreméltóbb a kifejlesztés alatt álló, többfeladatú, időjárást és céldetektálási feladatokat párhuzamosan megoldó, 76 alcsatornát mindkét polarizációban feldolgozó rádiólokátor [8]. Az aktív, digitálisan vezérelt fázisantenna hatásos izotróp antennához viszonyított nyeresége $85 \mathrm{dBW}$, átlagosan $40 \mathrm{~dB}$ oldalszintekkel, míg az antennanyaláb irányba állításának hibája kevesebb, mint $0,04^{\circ}$. A 8. ábrán látható a Lockheed Martin cég által nemzetközi finanszírozással kifejlesztett AN/SPY-7(V)1 többfeladatú távolfelderítő radar [9]. A szerző véleménye szerint ez a radar aránylag rövid idő alatt, alacsony költséggel tovább fejleszthető a HyW megjelenése által okozott kihívások megoldására is.

A nagy hatótávolságú VHF-radarok a NATO-ban történő széleskörű alaklamzásának szükségessége már évekkel ezelőtt felmerült [10]. Ugyanakkor napjainkban egyedül a lengyel radarszakemberek állnak közel egy nagy teljesítményü VHF-rádiólokátor kifejlesztéséhez és rendszerbe állításához. A 9. ábrán látható radar, harcászati alkalmazásától függően mechanikusan állítható vízszintes irányba - pl. hagyományos célok ellen -, vagy függőleges pozícióba helyezve, polarizációs antennarendszerét működteti, pl. harcászati rakéták detektálására. A közeljövőben valószínüsíthető a magyar és a lengyel szakemberek együttműködése egy modulárisan fejleszthető közös radarplatform kialakítására.

Meg kell jegyezni, hogy az új típusú radarrendszerek hálózatainak kialakításához komolyabb rendszertechnikai kihívásoknak kell megfelelni, mint az egymagában üze- 
[3] M. Peck. „Worried About Russian And Chinese Hypersonic Weapons? DARPA Isn't" The National Interest, 2020.02.13. Elérés: 2020. 11. 10. https://nationalinterest.org/blog/buzz/worried-aboutrussian-and-chinese-hypersonic-weapons-darpaisnt-123261;

[4] Lockheed Martin Co. „Revolutionizing Hypersonic Technologies” Elérés: 2020. 11. 10. https://www.lockheedmartin.com/en-us/capabilities/ hypersonics.html;

[5] István Balajti. „Performance of Air Surveillance requirements against Electronics Warfare and Hypersonic Weapons with Modernized Traditional Radar Networks" Aerospace and Electronic Systems Magazine (2021. kiadás alatt);

melő, napjainkban széles körben elterjedt IT hálózatcsomag alapon szervezett radarhálózatoknak. Ezért az új, fejlesztés alatt lévő radarok, egyedi paramétereiket tekintve hagyományos telepítési módokkal, csak az orosz Protivnik (Противник) radarcsalád műszaki performanciáit érhetik el. A megvalósítás előtt álló legnagyobb kihívások a békeidőben nem kellően értékelt, elektronikai ellentevékenység hatékonyságával függnek össze. Szerencsére az utóbbi időben újra egyre komolyabb figyelmet fordítanak az elektronikai harc jelentőségére $[11,12]$.

\section{Összegzés}

A tanulmány bemutatta, hogy a HyW-fegyverek ellen napjaink légvédelmi rendszerei nem képesek hatékonyan tevékenykedni, mivel a légtérellenőrző radarok eddig elvárt képességei és mérési szabadságfokához képest, a HyWrendszerek megnövelt támadási szabadságfokkal és lehetőségekkel rendelkeznek. A harcászati-hadászati ballisztikus rakéták által kifejtett védelem lehetőségei is rendkívüli mértékben beszűkülnek, mivel csupán az indítás fázisának detektálására alkalmasak. Erre is csak akkor, ha az indítás nem repülőgépről, a szembenálló fél számára radarokkal ellenőrizhető térrészben történik.

A HyW megjelenésével bekövetkezett légvédelemmel kapcsolatos kihívások megoldásai közül a VHF-rádiólokátor-rendszer lehetőségei a legígéretesebbek, míg a modernizált, vagy teljesen új 3D, több polarizációval rendelkező sokcsatornás $L$ és $S$ sávú radarokkal a célútvonalak indítása és fenntartása, valamint a nem együttműködő célok részbeni azonosítása is megoldható. Ennek a munkának kicsi, de jelentős szegmense a VHF frekvenciatartomány minél hatékonyabb kihasználására irányul, amely ma már a civil felhasználók zavarása nélkül is lehetséges.

Megállapítható, hogy napjaink új kihívásainak való megfelelés, valamint az új polgári, katonai és gazdasági kihívások és a szakirodalmi hivatkozások összetettsége megkövetelik nemcsak a hadmérnöki tudás szinten tartását, de az elvárások harcászati-hadműveleti újragondolását is.

\section{IRODALOMJEGYZÉK}

[1] Mattes, P. W. „What is a Modern Integrated Air Defense System" Air Force Magazine 2019. 10. 01. Elérés: 2020. 11. 10.

https://www.airforcemag.com/article/What-is-aModern-Integrated-Air-Defense-System;

[2] Congressional Research Service. „Hypersonic Weapons: Background and Issues for Congress" Updated March 17, 2020.

https://crsreports.congress.gov/product/pdf/R/R45811;

[6] I. Kurucz. A honi rádiótechnikai egység (magasabbegység) harcvezetési és harctevékenységi folyamatainak korszerüsítése, a vezetéstechnikai eszközök rendszerbe állításával összhangban. Kandidátusi értekezés. Budapest, ZMKA. 1988;

[7] Weis, Matthias, Stephan Sandenbergh, Ferran Valdes, Peter Muller, Dominik Bok, Michael Kohler, Daniel O'Hagan, és Peter Knott. „Aspects of Next Generation Sensor/Radar Networks". In 2019 20th International Radar Symposium (IRS), 1-8. Ulm, Germany: IEEE, 2019. https://doi.org/10.23919/IRS.2019.8768188;

[8] Kowalski, Elizabeth, David Conway, Alexander Morris, és Christine Parry. „Multifunction Phased Array Radar Advanced Technology Demonstrator (MPAR ATD) Nearfield Testing and Fielding". In 2019 IEEE Radar Conference (RadarConf), 1-4. Boston, MA, USA: IEEE, 2019. https://doi.org/10.1109/RADAR.2019.8835837;

[9] „Four Nations to Be Protected with Lockheed Martin's Next Generation Radar" Lockheed Martin Elérés: 2020. 11. 10.

https://news.lockheedmartin.com/2020-01-14-FourNations-to-Be-Protected-with-Lockheed-Martins-NextGeneration-Radar;

[10] Balaiti, I., G. Kende, és E. Sinner. „Increased importance of VHF radars in ground-based air defense". IEEE Aerospace and Electronic Systems Magazine 27, sz. 1 (2012. január): 4-18. https://doi.org/10.1109/MAES.2012.6145436;

[11] A. De Martino. Introduction to Modern EW Systems, Second Edition, Artech House, 2018;

[12] I. Balajti. „Air Defense System Operation in the EW Space: Understanding where radar system capability exists within Electromagnetic Spectrum Operations (EMSO) for the military" Military Radar Conference, London, 27-29 August 2019, Elérés: 2020. 11. 10. https://www.defenceiq.com/events-militaryradar/ speakers/istvan-balajti.

\section{JEGYZETEK}

1 Lásd részletek a Zengőre tervezett 3D radarral kapcsolatban. Hasonló radar 1981 óta ma is üzemel Berlin (Tempelhof) közepén. 2 A robotrepülőgépeket fordítási hiba miatt, tévesen szárnyas rakétának vagy cirkáló rakétának nevezik. A robotrepülőgép aerodinamikai (nem ballisztikus) elven repülő pilóta nélküli eszköz, melynek a levegőben maradásához szükséges felhajtóerő a szárny és az áramló levegő kölcsönhatásaként keletkezik. A mozgásához szükséges tolóerőt a környezeti levegőt felhasználó sugárhajtómü termeli, nem rakétamotor (- Szerk.). Katonai terminológiai értelmező szótár Zrínyi Kiadó, 2015. 564. o. és Katonai Lexikon, Zrínyi Kiadó, 1985. 80. o. 